Paweł Borettini

Koło Naukowe Bibliotekoznawców

Uniwersytet Łódzki

\title{
Wpływ inicjatyw podejmowanych w kole naukowym na przygotowanie do wykonywania zawodu bibliotekarza na przykładzie Studenckiego Koła Naukowego Bibliotekoznawców Uniwersytetu Łódzkiego
}

\section{Studencki ruch naukowy po 1989 r.}

Zmiana ustroju wywalczona w 1989 r. pozytywnie wpłynęła na studencki ruch naukowy. Po okresie kontroli nadszedł czas na swobodny rozwój intelektualny. Studenckie organizacje zostały uwolnione od wpływów politycznych.

Po wejściu Polski do Unii Europejskiej możliwości studentów poszerzyły się. Mają oni możliwość dyskutowania na naukowych spotkaniach międzynarodowych czy w czasie wyjazdów i wymian zagranicznych. Powstają nowe organizacje studenckie, jak np. StRuNa zrzeszająca koła naukowe studentów i doktorantów z całej Polski ${ }^{1}$. Ruch naukowy w obecnej Polsce stale się rozwija. Studenci organizują konferencje naukowe, krajowe i międzynarodowe, kongresy, luźne spotkania, przygotowują wspólne przedsięwzięcia towarzyskie o skali ogólnopolskiej jak i lokalnej (ferie zimowe, pikniki naukowe).

Rola ruchu studenckiego pod względem działań, jakie były prowadzone w okresie Polskiej Rzeczpospolitej Ludowej, uległa gruntownym przemianom. Realia polityczne pozwoliły aby nie trzeba było, jak dawniej, stać na straży wolności słowa. Nie oznacza to jednak, że studenci polscy po roku 1989 nie potrafią się jednoczyć i wspólnie dochodzić swoich racji. Doskonały przykład może stanowić protest przeciwko ACTA. Wiele przykładów walki studentów o swoje prawa znaleźć można również w innych krajach, takich jak Chile $^{2}$ czy Anglia ${ }^{3}$.

${ }^{1}$ Zob.: STRUNA. Projekty naukowe studentów i doktorantów [online]. Dostępny w Internecie: <http://struna.edu.pl/> [data dostępu: 03.03.2013]; Organizacja ta prowadzi m.in. coroczny konkurs na najlepszą konferencję naukową w kraju, publikacje roku, opiekuna roku, sponsora roku.

${ }^{2}$ Stasiński M., Studenci $w$ Chile wracaja do walki o edukacje, „Gazeta Wyborcza" [online], z dnia 31.08.2012. Dostępny w Internecie: <http://wyborcza.pl/ 
Liczba działających w Polsce kół obecnie jest trudna do ustalenia. Nie wszystkie uczelnie (publiczne jak i niepubliczne) prowadzą dokładny rejestr organizacji studenckich. Uniwersytet Warszawski prowadzi taki spis w wersji online $^{4}$. Na uczelni warszawskiej działają obecnie 482 koła naukowe i artystyczne.

Studenckie koła naukowe funkcjonują jako organizacje zrzeszające studentów z poszczególnych uczelni/wydziałów (w zależności od wewnętrznych ustaleń). Wśród celów, jakie obierają, wyróżnić można (wg priorytetów):

1. Rozwój zainteresowań naukowych (praca naukowo-badawcza);

2. Organizacja konferencji, sympozjów, warsztatów, spotkań, dyskusji naukowych;

3. Wyjazdy naukowo-badawcze (inne niż w pkt. 2);

4. Działalność na rzecz społeczeństwa lokalnego i akademickiego.

Na tej podstawie poszczególne uczelnie ustalają własne (bardzo podobne) definicje studenckiego koła naukowego. Uniwersytet Łódzki za koło naukowe uznaje:

uczelnianą organizację studencką/doktorancką - formę aktywności naukowej, artystycznej lub sportowej studentów/doktorantów poszerzającą ich zainteresowania związane z realizowanym programem naukowo-dydaktycznym ${ }^{5}$.

Przedstawiona powyżej ogólna definicja koła naukowego pozwala na dużą swobodę działalności naukowej i społecznej prowadzonej pod tą nazwą. Koła naukowe umożliwiają rozwój pasji naukowych oraz dzielenie się swoimi zainteresowaniami, które łatwo włączyć do zakresu działalności (np. te związane z filmem, sportem, a nawet florystyka).

1,76842,12393913,Studenci_w_Chile_wracaja_do_walki_o_edukacje.html> [data dostępu: 25.02.2013].

$3 \mathrm{asw} / \mathrm{mc} /$, W. Brytania: protest 10 tys. studentów przeciw rosnacym kosztom studiów [online]. Dostępny w Internecie: <http://www.google.com/hostednews/epa/article/ALeqM5iTGT7mhgUV1AVc9P9klYxEmKMryg?docId=12680661> [data dostępu: 25.02.2013].

${ }^{4}$ Wykaz Studenckich Kół Naukowych i Artystycznych Uniwersytetu Warszawskiego [online]. Dostępny w Internecie: 〈http://www.rada.uw.edu.pl/baza.php> [data dostępu: 02.06.2012].

Zarzadzenie nr 12 Rektora Uniwersytetu Łódzkiego z dnia 8.11.2011 $w$ sprawie: zasad tworzenia, funkcjonowania i finansowania kót naukowych, artystycznych $i$ sportowych $w$ Uniwersytecie Łódzkim. W: Uchwały Senatu, zarządzenie Rektora, Kanclerza UŁ, regulaminy, akty prawne [online]. Dostępny w Internecie: <http://www.uni.lodz.pl/prawo/uchwala,szczegoly,5298> [data dostępu: 7.05.2012]. 


\section{Działalność w kole naukowym a przyszłe życie zawodowe}

Okres studiów to dla wielu czas wytężonej pracy umysłowej. Najczęściej spotykanym modelem studenta, jaki prezentuje się w polskim świecie akademickim, jest osoba nastawiona na zdobycie uprawnień umożliwiających pracę w wyuczonym zawodzie. Na uczelniach polskich studiują żacy chętnie podejmujący inicjatywy wiążące się $\mathrm{z}$ wypełnianiem ponadprogramowych zadań. Bardzo często jedyną rekompensatą, jaką otrzymują w zamian za poświęcony czas, jest satysfakcja i zdobyte doświadczenie. Studenckie koła naukowe ułatwiają absolwentom studiów pracę oraz włączenie się do zawodu. Udział w studenckich kołach naukowych pozwala na poszerzenie wiedzy i umiejętności, przydatnych w późniejszej pracy. Koła kształtują i rozwijają pasję swoich członków. W czasie studiów każdy z młodych badaczy ma możliwość rozwoju umiejętności badawczych, wytrwałości i osiagania wyznaczonego celu.

O możliwościach wiążących się z czynnym udziałem w studenckich kołach naukowych Medard Masłowski pisze:

Wiedza i umiejętności zdobyte w kołach naukowych przydatne będą nie tylko $\mathrm{w}$ pracy naukowej $\mathrm{w}$ uczelni czy też $\mathrm{w}$ prowadzeniu prac naukowych poza uczelnią - w instytutach przemysłowych, zakładach doświadczalnych. Są one przydatne w każdym miejscu przyszłej pracy absolwenta szkoły wyższej, a wiec również w hucie, kopalni itp. bowiem - grupując ambitnych i zdolnych studentów - koła kształtują nawyki i przyzwyczajenia, rozbudzają pasję do poszukiwania nowych rozwiązań, [...] potrzeby racjonalizacji, usuwania nawet drobnych uchybień, niedbałości lub złych przyzwyczajeń. W rezultacie praca w kołach pozostawia trwałe ślady w psychice członków kół, kształcąc w nich zdolności badawcze, [...] czynną postawę w przyszłej pracy zawodowej. Dlatego też koła należy uważać za pierwszy, niezwykle ważny element systemu kształcenia kadr naukowych. Można by więc zakwestionować słuszność przyznawania stypendiów naukowych studentom spoza kół naukowych $[\ldots]^{6}$.

\section{Doświadczenia członków Studenckiego Koła Naukowego Bibliotekoznawców UŁ}

Przykładem zdobywania doświadczenia w trakcie studiów (poza obowiązkowymi praktykami), niezbędnego w przyszłym życiu zawodowym, jest działalność Studenckiego Koła Naukowego Bibliotekoznawców Uniwersytetu

${ }^{6}$ Masłowski M.: Studencki ruch naukowy w XX-leciu ZSP. „Życie Szkoły Wyższej”, $1970 \mathrm{nr}$ 4, s. 46. 
Łódzkiego. W trakcie każdej inicjatywy przygotowywanej w Kole student zdobywa doświadczenie, wiedzę i umiejętności ${ }^{7}$.

Praca Koła Naukowego przebiega w każdym roku akademickim wielotorowo. Wspólnie z opiekunem Koła studenci konsultują co roku swoje tematy badawcze, pomysły na akcje popularyzujące czytelnictwo, zgłaszają chęć organizacji konferencji.

Jedną z ważniejszych zorganizowanych inicjatyw była organizacja kursu komputerowego dla słuchaczy Łódzkiego Uniwersytetu Trzeciego Wieku. W trakcie sześciu spotkań zaznajomiono uczestników z nowymi technologiami, nadto - w wyniku badania ankietowego -zapoznano się $\mathrm{z}$ upodobaniami, zachowaniami i gustami czytelniczymi osób starszych oraz stopniem ich wiedzy i znajomości nowych technologii. Celem kursu było również ćwiczenie umiejętności dydaktycznych w trakcie przekazywania treści słuchaczom.

Kolejnym przedsięwzięciem, w którym udział wzięli studenci należący do Koła, była ogólnokrajowa akcja „Uniwersytet Łódzki dla Dzieci” organizowana od roku akademickiego 2010/2011. Cykliczne spotkania z młodymi studentami (w wieku 7-12 lat) odbywające się w jeden weekend miesiąca pozwoliły prowadzącym na zdobycie wiedzy z zakresu upodobań i wyborów czytelniczych u bardzo młodych osób, stopnia ich oczytania, oraz nabyć doświadczenie z zakresu możliwości przyswajania przez nie wiadomości. Adepci zawodu nauczycielskiego ćwiczyli własne umiejętności dydaktyczne, rozwijali zdolności wychowawcze, niekiedy po raz pierwszy występowali w roli prowadzącego zajęcia dydaktyczne.

Członkowie Koła podejmowali się współorganizowania wycieczek np. dla dzieci ze Szkoły Podstawowej nr 137 w Łodzi do Biblioteki Uniwersytetu Łódzkiego. Inicjatywa wymagała organizacji i realizacji kolejnych etapów przedsięwzięcia. Współorganizatorzy dowiedzieli się jakich formalności nale-

${ }^{7}$ Działalność Studenckiego Koła Naukowego Bibliotekoznawców UŁ udokumentowano w artykułach: Gruszka Z.: Z doświadczeń Studenckiego Koła Naukowego Bibliotekoznawców Uniwersytetu Łódzkiego w organizacji kursu komputerowego dla stuchaczy Łódzkiego Uniwersytetu Trzeciego Wieku. „Biuletyn EBIB” 2007, nr 6 (87) [dokument elektroniczny]. Dostępny w Internecie: <http://www.ebib.pl/2007/ 87/a.php?gruszka> [data dostępu: 02.06.2012]; Ladorucki J.: Koło naukowe jako szkota twórczego działania [W:] Historia i współczesność w badaniach bibliologicznych. red. J. Konieczna. Łódź 2007, s. 185-189; tenże: Studenckie Koło Naukowe Bibliotekoznawców Uniwersytetu Łódzkiego w latach 2000-2008 [W:] Tradycyjne i nowoczesne bibliotekarstwo w oczach studentów informacji naukowej i bibliotekoznawstwa: materiaty z I ogólnopolskiej konferencji naukowej „Biblioteka obiekt - idea wczoraj, dziś, jutro”, (Łódź, 18-19 maja 2007 r.) i I ogólnopolskiej konferencji studenckich kót naukowych „Elektroniczne oblicze biblioteki”, (Lublin, 11 kwietnia 2008 r.).Red. J. Ladorucki i R. Malesa, Kraków 2009, s. 11-20 oraz w książce: Profesjonalna biblioteka: materiały pokonferencyjne Studenckiego Koła Naukowego Bibliotekoznawców Uniwersytetu Łódzkiego. Oprac. Z. Gruszka. Łódź 2009. - ISBN 978-83-7525-362-7. 
ży dopełnić, w jakiej kolejności powinny być realizowanie zadania związane $\mathrm{z}$ informowaniem odwiedzanych instytucji (prośby i wnioski przedkładane w Bibliotece Uniwersytetu Łódzkiego i SP nr 137 w Łodzi). Przez cały czas studenci utrzymywali kontakt pisemny (dokumenty informacyjne) i telefoniczny ze szkołą. Przedsięwzięcie to pozwoliło studentom dowiedzieć się, jak powinny wyglądać prawidłowo sporządzone pisma urzędowe.

W Katedrze Bibliotekoznawstwa i Informacji Naukowej Uniwersytetu Łódzkiego, przy której działa Koło, jego członkowie regularnie sporządzają wystawy tematyczne wykorzystując w tym celu dostępne gabloty. W roku akademickim 2011/2012 zorganizowano m.in. wystawy: pierwszą związaną z ekslibrisami umieszczanymi na pocztówkach, drugą - stałą wystawę wszystkich numerów czasopisma wydawanego przez Koło pt. „Nieczytelna Sygnatura. Niezgulnik Studencki”. Praca tego typu wyrabia w przyszłych bibliotekarzach umiejętność selekcji materiałów wstępnie przeznaczonych do skomponowania estetycznej i zarazem interesującej dla odbiorcy formy przekazu wizualnego.

Opracowywanie wyników badań, które są w późniejszym czasie publikowane w zbiorach pokonferencyjnych czy fachowych czasopismach, pełne przygotowanie czasopisma studenckiego, pozwala na nabycie umiejętności z zakresu pracy nad tekstem naukowym i popularnonaukowym, zaznajamia ze składem technicznym dokumentów, uczy typografii. Charakter pracy wyrabia u studentów umiejętność planowania zadań, gospodarowania powierzonymi materiałami i finansami, uczy pracy w zespole.

Studenci należący do Koła niemal co roku występują w roli organizatora studenckiej konferencji naukowej bądź uczestniczą w przygotowaniach i organizacji tego typu przedsięwzięć zainicjowanych przez Katedrę. Aktywność w tym zakresie często dotyczy pozyskiwania sponsorów, patronów medialnych, organizowania upominków dla prelegentów. Najważniejsze jednak są umiejętności związane z kwestiami formalnymi tj. zaproszenia, potwierdzanie przybycia, opieka nad gośćmi, informowanie o możliwościach noclegu, układanie programu wystąpień. Studenci dbają o stronę techniczną przedsięwzięcia, opiekują się sprzętem multimedialnym, projektują programy imprez, dyplomy $\mathrm{z}$ podziękowaniami lub dyplomy uczestnictwa w konferencji. To ważna działalność, często później pożądana przez pracodawców. Łódzcy studenci należący do Koła dbają również o bieżące informowanie o swojej działalności oraz przekazywaniu ważnych i ciekawych informacji społeczności studenckiej. W roku 2005 zapoczątkowano prowadzenie strony internetowej. Obecnie dostępna jest druga wersja, w formie bloga, zamieszczona pod adresem www.bibliotekoznawcy.uni.lodz.pl. Dbanie o wizerunek w sieci sprawia, iż studenci szkolą się w zakresie umiejętności technicznych tj. HTML, CSS oraz z zakresu i sposobów promowania działań Koła. 
Każdego roku studenci z Koła uczestniczą w wyjazdach do ośrodków naukowych w Polsce. Najczęściej odwiedzanymi miastami są: Kraków, Wrocław, Warszawa, i Katowice. Wyjazd naukowy to przede wszystkim możliwość zapoznania się $\mathrm{z}$ funkcjonowaniem innych ośrodków akademickich, zwiedzenia ważnych bibliotek, muzeów, zabytków. Wiele czynności związanych z organizacją wyjazdów naukowych studenci wykonują samodzielnie.

Nową inicjatywą koła naukowego są organizowane w Katedrze Bibliotekoznawstwa i Informacji Naukowej UŁ debaty oksfordzkie. Każde spotkanie polega na dyskusji grupy zwolenników i przeciwników postawionej tezy; bierze w nim też udział publiczność. Dotychczas miały miejsce dwie debaty, z której jedna z nich została zatytułowana: Czy audiobook jest książką? Druga dotyczyła czytelnictwa.

Niektórzy członkowie Koła decydują się na zagraniczne wyjazdy wakacyjne w formie wolontariatu. Kierunkami wypraw naukowych były dotychczas Stany Zjednoczone Ameryki (Agata Walczak, Zbigniew Gruszka - pracownicy Katedry ze stopniem doktora) oraz Finlandia (Ewelina Makowska - obecnie doktorantka w Katedrze Bibliotekoznawstwa i Informacji Naukowej UŁ).

\section{Podsumowanie}

Potwierdzeniem wysokiej rangi, jaką daje absolwentowi kierunku studencka działalność w kołach naukowych, są opinie pracodawców. Joanna Delbar, prezes i założyciel firmy Telma Group Communications, specjalizującej się w public relations, przyznaje, że w trakcie rekrutacji bierze pod uwagę jedynie kandydatów, którzy mogą okazać potwierdzenie działalności w studenckich kołach naukowych ${ }^{8}$. Portal „Młodzi w Łodzi”, oferujący staże i praktyki dla studentów i absolwentów wyższych uczelni w formularzach rekrutacyjnych posiada rubryki umożliwiające wykazanie, jak wyglądała jego aktywna działalność naukowa i społeczna w trakcie studiów.

Koła naukowe oferują doskonały sposób nieodpłatnego zdobywania doświadczenia w czasie studiów. Działającym w strukturach kół naukowych osobom łatwiej jest zdobyć ofertę stażu bądź praktyk. Istnieje również duże prawdopodobieństwo, że po ich zakończeniu oraz po ukończeniu studiów, pracodawca chętniej zaoferuje zatrudnienie. Organizacja wszystkich przedsięwzięć w Kole Naukowym wymaga dużego poświęcenia i zaangażowania ze strony studentów przy jednoczesnym dopełnianiu obowiązków związanych $\mathrm{z}$ trybem nauczania. Dzięki temu członkowie koła naukowego efektywniej uczą się planowej organizacji i pracy pod presją czasu, orientując swoje dzia-

\footnotetext{
${ }^{8}$ Opinia Joanny Delbar wygłoszona dnia 17.11.2011 r. w trakcie prelekcji pt.: Polski rynek PR. Etyka i etykieta w zawodzie PR-owca na Wydziale Zarządzania Uniwersytetu Łódzkiego.
}

80 
łania na konkretny cel i efekt. Studenckie koła naukowe stanowią szkołę twórczego działania, będącą doskonałym uzupełnieniem i polem do wykorzystywania wiadomości zdobywanych $\mathrm{w}$ podstawowym zakresie nauczania; dodatkowo umożliwiają zdobywanie nowych doświadczeń.

\section{Bibliografia}

1. a s w/m c/, W. Brytania: protest 10 tys. studentów przeciw rosnacym kosztom studiów [online]. Dostępny w Internecie: <http://www.google.com /hostednews/epa/article/ALeqM5iTGT7mhgUV1AVc9P9klYxEmKMryg?docId= 12680661> [data dostępu: 25.02.2013]

2. Grusz k a Z.: Z doświadczeń Studenckiego Koła Naukowego Bibliotekoznawców Uniwersytetu Łódzkiego w organizacji kursu komputerowego dla słuchaczy Łódzkiego Uniwersytetu Trzeciego Wieku. „Biuletyn EBIB” 2007, nr 6 (87) [dokument elektroniczny]. Dostępny w Internecie: <http://www.ebib.pl/ 2007/87/a.php?gruszka> [data dostępu: 02.06.2012]

3. L a d or u c ki J .: Koło naukowe jako szkota twórczego dziatania [W:] Historia $i$ wspótczesność w badaniach bibliologicznych. red. J. Konieczna. Łódź 2007, s. $185-189$

4. Lad or u cki J.: Studenckie Koto Naukowe Bibliotekoznawców Uniwersytetu Łódzkiego w latach 2000-2008 [W:] Tradycyjne i nowoczesne bibliotekarstwo woczach studentów informacji naukowej $i$ bibliotekoznawstwa: materiaty z I ogólnopolskiej konferencji naukowej „Biblioteka obiekt - idea wczoraj, dziś, jutro", (Łódź, 18-19 maja 2007 r.) i I ogólnopolskiej konferencji studenckich kót naukowych „Elektroniczne oblicze biblioteki”, (Lublin, 11 kwietnia 2008 r.).Red. J. Ladorucki i R. Malesa, Kraków 2009, s. 11-20

5. Masłowski M.: Studencki ruch naukowy w XX-leciu ZSP. „Życie Szkoły Wyższej”, $1970 \mathrm{nr}$ 4, s. 42-51

6. Profesjonalna biblioteka: materiaty pokonferencyjne Studenckiego Kota Naukowego Bibliotekoznawców Uniwersytetu Łódzkiego. Oprac. Z. Gruszka. Łódź 2009. - ISBN 978-83-7525-362-7

7. S ta siński M., Studenci w Chile wracaja do walki o edukacje, „Gazeta Wyborcza" [online], z dnia 31.08.2012. Dostępny w Internecie: <http://wyborcza.pl/1,76842,12393913,Studenci_w_Chile_wracaja_do_walki_o_edukacje.html> [data dostępu: 25.02.2013]

8. Wykaz Studenckich Kót Naukowych i Artystycznych Uniwersytetu Warszawskiego [online]. Dostępny w Internecie: 〈http://www.rada.uw.edu.pl/baza.php> [data dostępu: 02.06.2012]

9. Zarzadzenie nr 12 Rektora Uniwersytetu Łódzkiego z dnia 8.11.2011 w sprawie: zasad tworzenia, funkcjonowania i finansowania kót naukowych, artystycznych $i$ sportowych w Uniwersytecie Łódzkim [W:] Uchwały Senatu, Zarządzenia Rektora, Kanclerza UŁ, regulaminy, akty prawne [online]. Dostępny w Internecie: http://www.uni.lodz.pl/prawo/uchwala,szczegoly,5298 [Data dostępu: 7.05. 2012] 